\title{
EARLY OBSERVATIONS OF BARRED OWL IN ALBERTA
}

EDGAR T. JONES, 6115 - 141st Street, Edmonton, Alberta. T6H 4A6

During searches for the Great Gray Owl during the 1950s and 1960s it became evident from observations that the Barred Owl was fairly evenly distributed in Alberta, particularly in the northern forests and the heavily forested foothill regions of Alberta. The following are edited extracts from my notes covering this early period; all except the Tete Jaune, B.C. record are within Alberta.

18 May 1953 Corbett Creek. Secondary wing feather of this species picked up in woods.

18 November 1953 Calling Lake. A specimen sent in had been caught in an Indian trappers set on this date.

15 March 1954 Fawcett, 6 mi. west. A bird was sent in to Dr. A. E. Oeming and myself by R. E. Junck. It was apparently shot by $E$. Joliffe on this date. I mounted this bird for Dr. Oeming.

11 April 1954 Timeau (north of Ft. Assiniboine). One adult seen and photographed in very heavy mixed woods just off oil cut line.

6 May 1954 Obed. Two badly decayed adult birds picked up from a trappers cabin where they had been poletrapped earlier in the year.

15 May 1954 Rocky Mountain House, 40 mi. west. Carcass of adult found near a Great Gray Owl's nest - badly decomposed.

11 August 1954 Flatbush. Owl seen at nest box \#5 and later a feather found beneath the nest box. As near as could be determined the box had been used for roosting, rather than for nesting.

21 June 1961 Tete Jaune, B.C. Single adult heard calling on side of heavily wooded mountain slope - north side of McBride Road, Hwy. 16.

6 May 1963 Edmonton. Single bird heard calling near house from valley of White Mud Creek. Hooting continued for several days until the bird was seen 11 May in daylight. Bird stayed in area until late July and likely nested.

28 May 1963 Miette River, Jasper National Park. Single bird heard hooting near our camp site last night and observed this day.

28 May 1966 Edmonton. Discovered a nest containing three half grown young; 30 feet up in a dead poplar. Female flushed off when tree was kicked. The three young were photographed and banded. This nest was thought to be the first authentic nesting record for Alberta.

16 April 1968 Edmonton. Another nest in the White Mud Creek valley close to the location of the 28 May 1966 nest was found in a poplar stump 25 feet up. Probably the same pair as in 1966. The nest contained three eggs when located and when checked a few days later contained only one egg which also disappeared.

2 May 1968 Lac La Nonne. An owl heard and then observed on the northwest corner of the lake - no suitable nesting stumps in area. 
19 June 1968 Coalspur. A single owl was heard calling eight times from a ridge to the east of the Provincial Government campsite where we were camping.

28 August 1971 Edmonton. A bird was heard calling in White Mud Creek and again on the edge of our yard for approximately two hours.

10 May 1981 Jasper. A single bird was heard calling five times at approximately 9:00 p.m. on the Sky Tram Trail just below Whistler's Hostel.

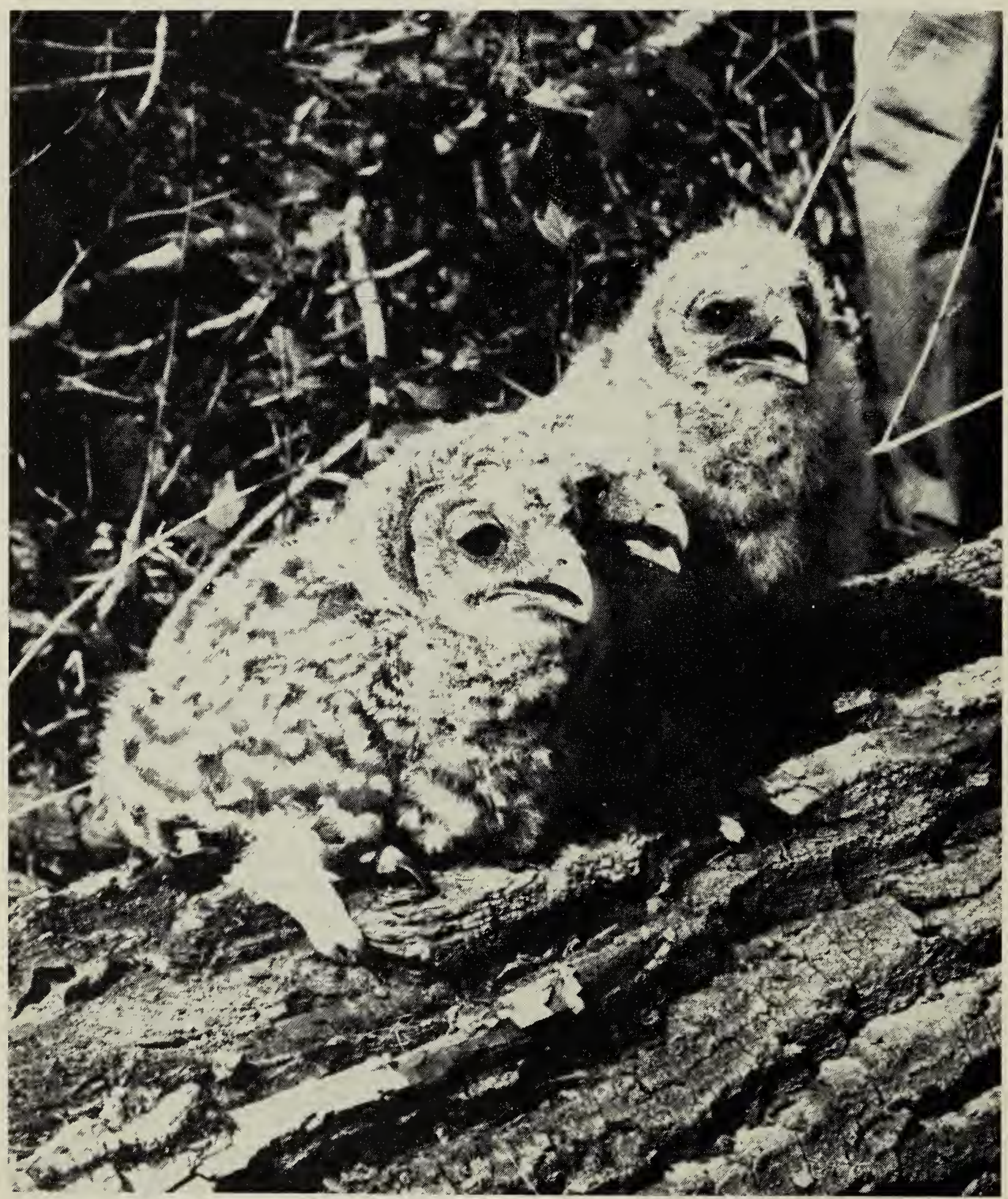

Young from nest in Whitemud Creek Valley banded 28 May 1966

Edgar T. Jones 